\title{
Equilibrium Sovereign Default with Endogenous Exchange Rate Depreciation*
}

\author{
Sergey V. Popov ${ }^{\dagger}$ \\ David G. Wiczer \\ Department of Economics, University of Illinois \\ Department of Economics, University of Illinois \\ popov2@illinois.edu \\ dwiczer@illinois.edu
}

February 6, 2010

\begin{abstract}
Sovereign default often affects country's trade relations. The defaulter's currency depreciates while trade volume falls drastically. To explain this connection, this study proposes a model to incorporate real depreciation along with sovereign bankruptcy. Defaulters must exchange more of their own goods for imports, which stimulates an adjustment to the equilibrium exchange rate. We demonstrate that a default episode can imply up to a $30 \%$ real depreciation. This matches the depreciations observed in crisis events for developing countries. To avoid this, countries are willing to maintain borrowing obligations up to a realistic level of debt.
\end{abstract}

Keywords: endogenous default, endogenous exchange rate, trade balance.

JEL: F34, F11, F17.

\footnotetext{
*We are grateful to Dan Bernhardt, Anne Villamil, Rui Zhao and Makoto Nakajima for productive discussions and numerous comments; we thank Volodymyr Lugovskyy, Anton Cheremukhin, Daniil Manaenkov and Demian Pouzo for their careful revisions to early versions. We also thank participants of Missouri Economics Conference 2008, 4th Annual Graduate Student Conference in Washington University and Presenting Papers seminar series in University of Illinois for useful suggestions. All errors are ours.

${ }^{\dagger}$ Corresponding author.
} 


\section{Introduction}

Sovereign default has major repercussions to a country's trade relations, almost always involving large changes in traded quantities and relative prices. In this study, we offer a model that makes three major contributions to understanding these extreme circumstances: it explains trade behavior after default, shows that defaults may occur even without negative income shocks and demonstrates that reasonable levels of debt can be sustained by the threat of a penalty to traded goods. We consider jointly goods and capital flows, which allows us to study the interaction between goods and incomplete international capital markets with limited enforceability. Previous literature tends to avoid modeling the flow of goods.

The penalty that we introduce emphasizes the importance of the composition of consumption. Whereas Bulow and Rogoff (1989) demonstrate that debt cannot be sustained by penalties that affect only the ability to smooth consumption, i.e. capital market exclusion; while prior works had only considered a penalty to diminish the level of consumption. We show that forcible deviation from optimal composition, through trade penalties, can also be an effective deterrent. This change in composition is part in parcel with currency depreciation, the price of foreign goods adjusts to the new quantities. Thus, the link between depreciations and default, documented below, is not just incidental, the composition penalty enables debt and default, and implies depreciation.

The motivation for our work comes from clear evidence that a country's standing in international debt markets affects its trade relations. Through our framework, we are able to consider how trade penalties affect its decision to maintain debt obligations. We can see that defaulters incur depreciation and a change in traded quantities. Our model allows to quantify the welfare implications of these effects, and thereby investigate whether a trade penalty is an effective deterrent to default. We answer affirmatively: faced with a trade penalty, countries will sustain realistic levels of debt before defaulting.

To add specificity, we consider a country with access to a single bond to smooth stochastic income fluctuations. These obligations cannot be directly enforced, but defaulters are punished 
by an increase in the cost of importing foreign goods. This penalty causes enough welfare loss to dissuade default up to a certain debt level. This welfare loss stems from a composition change in the consumption basket. Faced with these penalties, the consumption mix of domestic and foreign goods adjusts and the exchange rate is determined in equilibrium.

\subsection{Previous literature}

The current literature on endogenous defaults considers countries fundamentally self-sufficient, but with access to international markets to smooth their income fluctuations. A country's income fluctuations determine its demand for credit, and defaulters face market exclusion and an exogenous penalty to their income stream. Arellano (2008) exemplifies this type of model, in which endogenous default is a choice between servicing a sovereign's debt or defaulting and suffering an ad hoc penalty to output. Bulow and Rogoff (1989) showed that some sort of penalty to defaulters is required to sustain a positive level of debt in equilibrium, as a purely reputational penalty-a temporary exclusion from credit markets - is not enough. As in Arellano (2008), most studies have interpreted the penalty to a defaulter as a loss of output. Modeling assumptions for the penalty and process for generating income is then tightly intertwined, as demonstrated by Aguiar and Gopinath (2006), which uses a process with a stochastic trend and then is able to use a more general form of an income penalty.

The income penalty is motivated by an empirical finding that output on average falls after default. Tomz and Wright (2007), however, finds the link between "bad times" and default to be "surprisingly weak" - about $40 \%$ of the default episodes happen with above-trend output.

In the theoretical literature, a country's interaction with foreign countries is confined to the bond market, which provides imperfect insurance against future recessions. In contrast, many empirical studies demonstrate that international trade is severely affected by the default. Rose (2005) documents that default reduces international trade by $8 \%$ for an extended period after default. He speculates that trade suffers after default because trade partners will not extend short-term credit after a sovereign default, raising the cost of cross-border trade. This is consistent with Arteta and Hale (2008), who finds that credit becomes scarce for private firms after a sovereign default. Aside from disruptions to financing, the existing barriers may worsen. Exporters are at the whim of other coun- 
try's trade officers, who can greatly increase the cost of trading goods by overzealous customs inspections or other non-tariff trade barriers. The time cost, coming from uncooperative trade officials, can add 10-30\% to the cost of imports, as estimated by Hummels (2001). Many of these costly bureaucratic barriers must be fungible and can be made more stringent for less-favored trade partners. Furthermore, many developing economies depend on favorable trade agreements and sourcing partnerships with the developed world. ${ }^{1}$ Without favored market access or the use of a trade partner transport infrastructure, the effect on the cost of exporting goods is similar to additional "iceberg" costs.

\subsection{Some Stylized Facts on Trade in Default}

De Paoli and Hoggarth (2006) explore defaults since 1975 and finds a strong link between currency crises and sovereign default. They propose an informal explanation for this observation related to nominal rigidities and potential central bank insolvency. Here, we expand on this finding: Table 1 shows that even when depreciation might not qualify as a crisis, defaulters usually experience a decline in their terms of trade. Though large changes to the nominal exchange rate sometimes occur, generally, the real depreciation actually accounts for most of the change in relative prices. Our study considers only the real phenomena - defaulters face an endogenous depreciation of their real exchange rate, the price of foreign goods denominated in terms of domestic goods.

Table 1 presents the gross changes over a year for defaulters' nominal effective exchange rate (NEER), real effective exchange rate (REER), export price and the fraction of expenditure on imports. Notice that the median defaulter has nearly the same depreciation in real exchange rate as in nominal exchange rate after a year's time. With higher frequency data, the NEER depreciation tends to be sharper, but the REER quickly catches up. In some cases, the nominal change is greater than the real, but in many of these instances, narrative evidence suggests mismanagement by the monetary authority or financial market overreaction. Table 1 reveals that nominal appreciation is rather uncommon.

Countries in default suffer a consistent drop of about $10 \%$ in the price of their exports in foreign markets; the distribution of price changes is more tightly clustered than the depreciation distribu-

\footnotetext{
${ }^{1} 195$ active bilateral trade agreements have been reported to the World Trade Organization by January 2009, any of which could be terminated in response to a financial episode and would effectively increase tariffs faced by a country's exporters.
} 


\begin{tabular}{|c|cccc|}
\hline \hline Gross change & NEER & REER & Export Prices & Imports/GDP \\
\hline Mean & 0.8492 & 0.8900 & 0.9184 & 0.8968 \\
Median & 0.9102 & 0.9220 & 0.9075 & 0.9211 \\
$\operatorname{Pr}<0.2$ & 0.6835 & 0.7861 & 0.8291 & 0.7773 \\
$\operatorname{Pr}<0.4$ & 0.8729 & 0.8688 & 0.8984 & 0.8978 \\
$\operatorname{Pr}<0.6$ & 0.9505 & 0.9429 & 0.9269 & 0.9436 \\
$\operatorname{Pr}<0.8$ & 1.0168 & 0.9755 & 1.0068 & 1.0070 \\
\hline
\end{tabular}

Table 1: One year effect of sovereign default.

tion. Because the REER weights their trading partners by volume of trade, it suggests that the fall in export prices is more pronounced with a country's more active trading partners. Defaulters receive fewer imports in return for the same number of export goods, a fall in export price, which might stimulate domestic households to substitute away from foreign goods, further affecting the exchange rate.

Even at high frequency, the depreciation is abrupt and follows the same trend as above, with REER slightly trailing NEER. In Figure 1, we show the exchange rate dynamics in two recent defaults, Ukraine and Paraguay. Note that in the Ukraine, real and nominal exchange rates move almost indistinguishably. This suggests that post-default currency depreciation is not only due to shaky sovereigns who impel hot capital to flee — instead something fundamental happens to cross-border exchange of real goods.

The data also reveal that households with bankrupt governments spend relatively less on imports, which have become more expensive following the price changes. This fact is an amalgam of competing forces: the substitution effect would decrease imports, and the income effect would also diminish the demand for imports, with imports as normal goods. On the other hand, average income is lower in default. The falling share of imports suggests that this latter effect is not as strong as the former. In our model too, imports fall as a share of spending. Though Tomz and Wright (2007) suggest that income is not a prerequisite of default, it does seem to reliably change trade flows. 

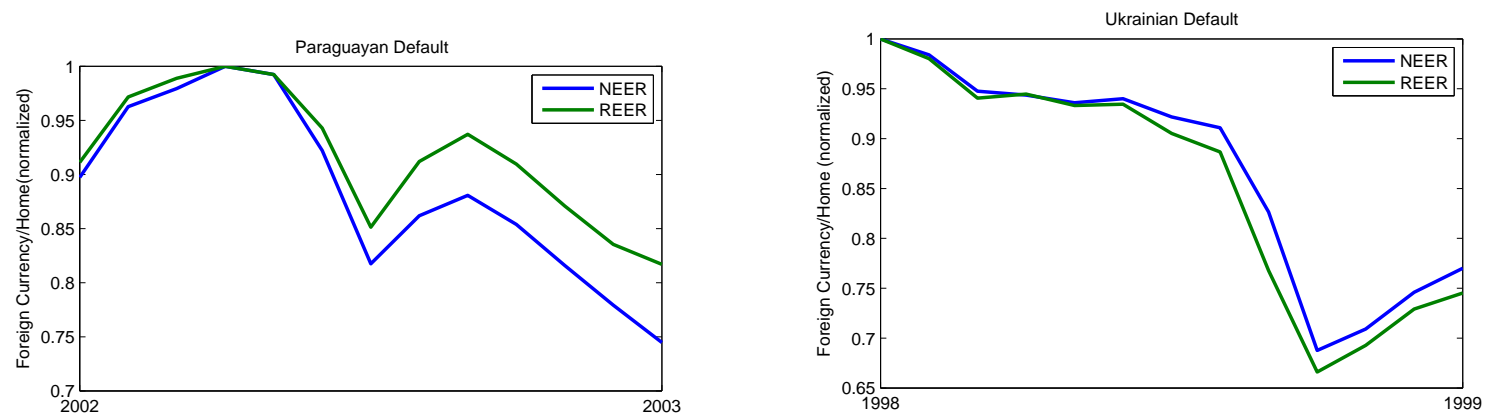

Figure 1: Dynamics of exchange rates in Paraguay and Ukraine, nominal and real. Exchange rates are normalized so that maximum value in the sample is 1.

\subsection{Trade Channel Penalty}

Bulow and Rogoff (1989) suggest that trade sanctions might sufficiently discourage default to support realistic levels of debt. They justify such trade disruptions by speculating that a country might rely on its reputation to maintain trade flows, which would be damaged by a default episode. They did not, however, model the trade channel penalty or making quantitative statements about its implications. Investigating the role of trade penalties further, Wright (2001) discusses the similarities between penalties to trade flows, assets or income. In some environments, they are equivalent, in that any of these penalties can create a welfare loss that dominates the gain from not reimbursing the loan. However, the trade penalty has advantages, as we demonstrate, because it generates richer, more realistic default behavior, and realistic changes in trade volume and exchange rate.

In introducing a trade channel penalty, this paper brings default models in line with the observed reaction of the external sector in default. Post-default, we consistently observe real depreciation and substitution away from imports. Without trade in goods one cannot account for the change consumption composition, which is a major source of welfare loss to defaulters.

To specify this trade channel penalty, we assume that default is punished by a deterioration of the terms of trade. At its extreme, this would be an absolute embargo, which was not uncommon historically when countries refused to pay their creditors. In the 1861 Mexican default, creditors actually seized the port of Veracruz (see Todd (1991)). Circumnavigating gunboats certainly increased the "iceberg costs" on Mexican exports. Though Tomz (2007) argues that outright military 
force only played a minor role in punishing defaulters, our evidence suggests that something impedes trade for defaulters. When choosing to default, the sovereign understands that it is bringing higher iceberg costs to its traders.

In our model, in which there are international markets for borrowing and consumption goods, the sovereign internalizes the demand of its citizens: to smooth marginal utility and to consume foreign goods. Thus, worse terms of trade is an incentive for the sovereign to stay current in its debt. Because the price of foreign goods is an equilibrium object after solving for demand and supply of trade goods, our model can address the extent to which sovereign default leads to real exchange rate depreciations. After default, a country's exports fetch fewer imports so consumers substitute to domestic production and, as quantities adjust, the exchange rate depreciates.

\section{The Model}

Our model of default extends the models of Eaton and Gersovitz (1981) and Arellano (2008), integrating a commodity space with both domestic and foreign goods. We describe a small open economy in which a government internalizes its citizens preferences over domestic goods, $c_{t}$, and imports, $m_{t}$. These goods are imperfect substitutes with constant elasticity, $\frac{1}{1-\kappa}$ in our formulation. The relative price of exports is the exchange rate, $e_{t}$. Imports are exchanged for exports, $x_{t}$ by import firms according to $m_{t}=f\left(x_{t}\right)$. Their profit, $\Pi_{t}$, goes back to households.

Asset markets are incomplete with one period bonds serving as the only insurance against shocks to the income stream, $y_{t}$. The sovereign borrows $b_{t}$ on behalf of its citizens from an international market paying a coupon $q_{t}$. Debt contracts are not enforceable, so the country may default. As punishment, the country suffers a deterioration in terms of trade and financial autarky for a random period of time.

The domestic country maximizes

$$
U\left(c_{t}, m_{t} ; \kappa, \alpha\right)
$$

(where $\kappa$ and $\alpha$ determine the relative preference for imports) subject to the income process and 
budget constraint

$$
\begin{aligned}
c_{t}+e_{t} m_{t}+b_{t} & =y_{t}+q_{t} b_{t+1}+\Pi_{t}, \\
\log y_{t} & =\rho \log y_{t-1}+\epsilon_{t}, \epsilon_{t} \sim \mathcal{N}\left(0, s^{2}\right)
\end{aligned}
$$

The importer transforms exports to imports according to

$$
m_{t}=f\left(x_{t}\right): f^{\prime}(\cdot) \geq 0, f^{\prime \prime}(\cdot) \leq 0 .
$$

In particular, we specify the import export technology to be $f\left(x_{t}\right)=\theta_{1}\left(x_{t}-\theta_{0}\right)^{\theta}$. This technology is a reduced-form representation of the rest of the world's demand for domestic goods. For $\theta<1$, the home country's exports receive diminishing returns in terms of imports. This is equivalent to assuming diminishing marginal utility of the country's goods to the foreign consumers. $\theta_{0}$ allows for fixed costs to exporting, though in our calibration we find its value to be small.

Certainly, we could motivate the demand coming from the rest of the world (ROW) with a structural formulation for preferences. However, from the point of view of the small open economy, only the ROW demand can be observed, and this demand function is sufficient to pick the optimal quantity of exports. Both estimating and imposing an explicit form for the ROW utility seems equally treacherous. From an economist's perspective, calibrating the preferences of the ROW is daunting because one must aggregate structural preferences, but the weighting of the relative importance of a trade partner is only observed in equilibrium. Aesthetically, a full optimization by the ROW might be preferable, but we choose to keep our model focused and parsimonious; our contribution is not why countries trade, but rather why they default.

Much of our analysis would go through with a simpler linear technology, $f\left(x_{t}\right)=\theta_{1} x_{t}$. With a linear technology, the trade channel penalty would cause depreciation in default, but the depreciation would be one-for-one with the size of the penalty. We would essentially be directly imposing the size of depreciation, instead of allowing it to be determined endogenously by preferences. Our preferred form matches the stylized facts to a greater extent. In particular, (with a linear technology) the depreciation would be the same size every time, but Table 1 reveals that this is not the case. 


\section{$2.1 \quad$ Timing}

Time is infinite and discrete. At the beginning of each period, a country's state variables - income, borrowing to repay, and default status - are common knowledge. The first choice is whether to default; then country chooses consumption, trade and borrowing policies. If the country is in good standing, it faces a coupon price schedule from its creditors who will charge a premium over the fixed world interest rate based upon the probability of default in the next period.

If the country defaults, then it experiences a terms-of-trade deterioration before its trade policy is set. The equilibrium exchange rate clears the international trade markets. As in Eaton and Gersovitz (1981), countries in default are in financial autarky, and their bond position reverts to zero. Unlike the aforementioned article, countries can leave this defaulted state each period with an exogenous probability of being "forgiven".

\subsection{Representative Household and Government}

The sovereign government internalizes the problem of the representative household. In particular,

household preferences take the form $u\left(c_{t}, m_{t} ; \kappa, \alpha\right)=\left[\alpha c_{t}^{\kappa}+(1-\alpha) m_{t}^{\kappa}\right]^{\frac{1-\sigma}{\kappa}} /(1-\sigma)$. We will formulate the representative household problem recursively. Given income realization, $y$, bond position, $b$, and the indicator of whether it is being punished, taking as exogenous the price of bonds, $q(\cdot, \cdot)$ and imports, $e(\cdot)$, the government solves two subproblems, one if it decides to default and one if it does not default. The solution to the non-default problem is summarized by the value function $V(b, y)$ and the defaulter's problem has value function $W(y)$. The default decision is the argmax of these two functions, and the government's value function, $U(b, y)$ is the envelope over the subproblem value functions, $V(\cdot, \cdot), W(\cdot)$. Formally, the government solves the Household Problem:

$$
U(b, y)=\max _{h \in\{0,1\}} h W(y)+(1-h) V(b, y),
$$

where $h \in\{0,1\}$ indicates default. Conditional on not defaulting this period, the Household's Problem In Good Standing is: 


$$
\begin{aligned}
V(b, y) & =\max _{c, m, b^{\prime}} u(c, m)+\beta E U\left(b^{\prime}, y^{\prime}\right), \\
\text { s.t. } & \\
c+e m+b & =y+q\left(y, b^{\prime}\right) b^{\prime}+\Pi, \\
\ln y^{\prime} & =\rho \ln y+\epsilon, \epsilon \sim \mathcal{N}\left(0, s^{2}\right) .
\end{aligned}
$$

The debt discount $q\left(y, b^{\prime}\right)$ adjusts the price of borrowing to accommodate the probability of default. By choosing $b^{\prime}=b_{0}$, the country accepts the contract that gives it $q\left(y, b_{0}\right) b_{0}$ units of home good this period and takes away $b_{0}$ units of home goods next period. Using discounts instead of returns permits banks to decide not lend at all, which may happen when default is nearly certain because of an extremely high level of debt, which imply an infinite interest rate.

If country chooses to default, then its value function is an optimal solution to The Household Problem In Default:

$$
\begin{aligned}
W(y) & =\max _{c, m} u(c, m)+\beta E\left(\phi W\left(y^{\prime}\right)+(1-\phi) U\left(0, y^{\prime}\right)\right), \\
\text { s.t. } & \\
c+e m & =y+\Pi, \\
\ln y^{\prime} & =\rho \ln y+\epsilon, \epsilon \sim \mathcal{N}\left(0, s^{2}\right) .
\end{aligned}
$$

\subsection{Importers}

The importers face a trade demand given by equation (4) from the rest of the world. Note, that the country does not face a perfectly elastic demand from the rest of the world. Instead, this is a "small country model" only in that the decisions of the country do not affect the demand of the rest of the world. In case of default, equation (4) is shifted to generate the terms of trade shock that serves as punishment.

Domestic importers take exports $x$ from their countrymen at the price of the consumption good and exchange them for $m$, taking their price $e$ as given. If the country is being punished for default, it receives fraction $1-\pi$ fewer imports. Their problem is summarized by Importer's Problem: 


$$
\begin{aligned}
\Pi(x, m, h) & =e m-x, \\
\text { s.t. } & \\
m & =(1-\pi)^{h} f(x) .
\end{aligned}
$$

Notice that the trade channel penalty, $1-\pi$ enters as if there were a sudden increase in iceberg costs. This is a conscious choice, intended to expose defaulters to trade barriers that increase the cost of sending their goods abroad. For example, country's exporters may find that its exports sit in customs longer after default, that foreign trade inspectors are more deliberate or, more benignly, that favorable trade agreements are canceled; this can be an efficient way of adding real costs of exporting, and Hummels (2001) shows how more time en route can be a trade barrier. Alternatively, one can think of country getting $\pi$ less imports for the same amount of exports as a crude defaulted debt renegotiation process.

Figure 2 depicts the effect of the trade penalty, given the concave functional form of $f(x)$. The export quantity is a distance from disposable income to consumption of home produced goods. The endogenous exchange rate, $e$ is the slope of the tangent.

\subsection{International Financial Markets}

Denote the default decision control $h(y, b)=\mathbb{I}(W(y)>V(y, b))$. It is equal to 1 when country announces default. World financial markets are risk-neutral but cannot enforce their debt contracts. They have perfect knowledge of the sovereign's problem, so they have zero profits and set $q\left(y, b^{\prime}\right)$ so that the expected return equals the international risk-free rate of return $R$. The credit market Zero Profit Condition is:

$$
q\left(y, b^{\prime}\right)=\frac{1-E\left[h\left(y^{\prime}, b^{\prime}\right)\right]}{1+R}
$$

\subsection{Recursive Equilibrium}

The Recursive Competitive Equilibrium is a collection of 


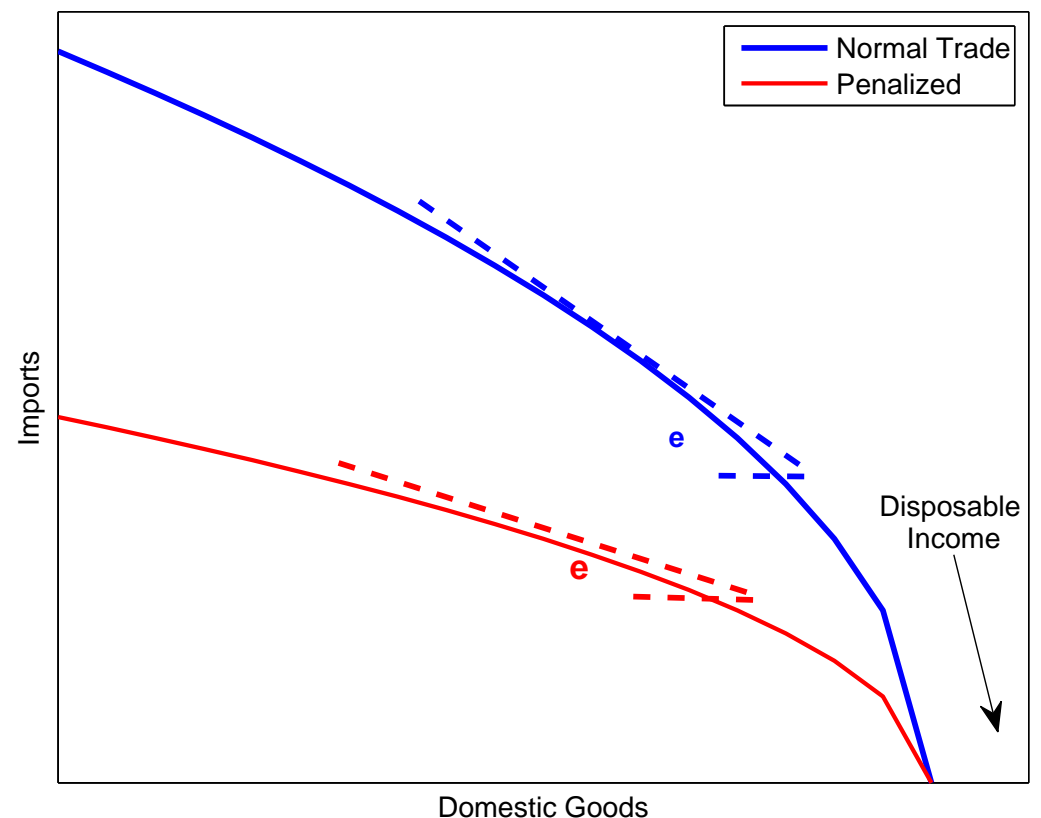

Figure 2: The export-import transformation function and the effect of the trade channel penalty

- consumer choice functions $\left(c_{V}(y, b), b_{V}^{\prime}(y, b), m_{V}(y, b)\right)$ when the country is not in default,

- consumer choice functions $\left(c_{W}(y, b), m_{W}(y, b)\right)$ when the country is in default,

- consumer's default choice function $h(y, b)$,

- consumer's value functions $(V(y, b), W(y), U(y, b))$,

- importer choice variables in no default state $\left(x_{V m}(y, b), m_{V m}(y, b), \Pi_{V}(y, b)\right)$

- importer choice variables in the default state $\left(x_{W m}(y), m_{W m}(y), \Pi_{W}(y)\right)$,

- and price variables $\left(e_{V}(y, b), e_{W}(y), q\left(y, b^{\prime}\right)\right)$

such that:

- $\left(c_{V}(y, b), b_{V}^{\prime}(y, b), m_{V}(y, b)\right)$ solve the Household's Problem In Default, given $\Pi_{V}(y, b)$, $e_{V}(y, b)$ and $U(y, b)$, and $V(y, b)$ is the value function of this problem. 
- $\left(c_{W}(y, b), m_{W}(y, b)\right)$ solve the Household's Problem In Good Standing, conditional on $\Pi_{W}(y), e_{W}(y)$ and $U(y, b)$, and $W(y)$ is the value function of this problem.

- $(h(y, b))$ solve the Household Problem conditional on $V(y, b)$ and $W(y)$, and $U(y, b)$ is the value function of this problem.

- $\left(x_{V m}(y, b), m_{V m}(y, b)\right)$ solve the Importer's Problem conditional on $e_{V}(y, b)$, and $\Pi_{V}(y, b)$ is the value function of this problem.

- $\left(x_{W m}(y), m_{W m}(y)\right)$ solve the Importer's Problem conditional on $e_{W}(y)$, and $\Pi_{W}(y)$ is the value function of this problem.

- $q\left(y, b^{\prime}\right)$ satisfies the Zero Profit Condition given on $h(y, b)$.

- $e_{V}(y, b)$ is such that import market clearing condition $m_{V}(y, b)=m_{V m}(y, b)$ holds.

- $e_{W}(y)$ is such that import market clearing condition $m_{W}(y)=m_{W m}(y)$ holds.

Equilibrium exists for the same reason as in Arellano (2008); our problem is separable between borrowing and consumption. After the value of borrowing for the next period is chosen, the allocation of available income between consumption and imports is maximizing monotone function upon compact set.

\section{Quantitative Evaluations}

To evaluate the predictive power of our model, we calibrate our baseline version to Argentine's historical data, following much other related research. Argentine experienced three international default occurrences, in 1982, 1989 and 2002. None of the restructuring periods were particularly long. All these defaults were accompanied by nominal exchange rate depreciation and non-zero trade balances.

\subsection{Quarterly Data}

Our parameter values come from our own estimates and Arellano (2008). Specifically, we estimated the parameters of income time series, the goods relative preference parameters, and import-export 
relationship parameters and borrowed the values of $R, \beta, \phi$ and $\sigma$. INDEC, National Institute of Statistics and Censuses, provides quarterly estimates of GDP composites, deseasonalized and in same-year prices, for years of 1993-2008. To make per capita values, we divide by the annual population of Argentina, obtained from CIA Factbook. To convert the import data from peso expenditure into quantities of foreign goods we used the real exchange rate taken from the European Central Bank website ${ }^{2}$.

The parameters that we used were estimated on the quarterly dataset from 1993 to 2008, and are provided in Table 2 .

Most of our estimates are close to similar estimations by others. In the international trade literature, most parameter estimates seem to be vigorously debated, though Ruhl (2003) nicely situates the discussion on the proper elasticity parameter $\kappa$. Compared to other international business cycle models, our elasticity estimate is slightly high.

For details on the estimation of our import-export parameters - $\theta, \theta_{0}, \theta_{1}$ - see Appendix B.3. We are not aware of others who have estimated a comparable functional. However, Das et al. (2001), using firm-level data, found fixed costs for export supply close to zero. This is consistent with our value for $\theta_{0}$. Hummels and Klenow (2005) analyzed the growth of exports from developing countries and found that up to $60 \%$ of the increase comes from the "extensive margin." Rather than deepening existing trade relationships, countries increase exports by diversifying their goods or partners. We take it as evidence that export markets quickly become satiated and justifies small $\theta$.

\subsection{Solving for the Recursive Equilibrium}

Since competition in the home market is perfect, the solution to the equilibrium is the same as solving with a centralized home economy in which the importer's problem is internal to the household. We call this the Centralized Equilibrium, and describe it in Appendix A.

Every period the country faces an import-generating technology, $f(x)$ as in equation 4 and allocates its consumption between imports and domestic production, as illustrated on Figure 2. Disposable income is $y+b-q\left(b^{\prime}(y, b)\right) b^{\prime}(y, b)$ if country can borrow and $y$ if the country cannot.

\footnotetext{
${ }^{2}$ From Statistical Data Warehouse section, located at http://sdw.ecb.europa.eu/
} 


\begin{tabular}{|c|c|c|c|}
\hline Parameter & Value & Explanation & Rationale \\
\hline $\begin{array}{l}\rho \\
s\end{array}$ & $\begin{array}{l}0.9849 \\
0.0258\end{array}$ & $\begin{array}{l}\text { Unconditional expected rate of return required } \\
\text { by international banking system. } \\
\text { Autocorrelation of log-output. } \\
\text { Standard Deviation of log-output. }\end{array}$ & $\begin{array}{l}\text { Quarterly return on US } \\
5 \text { year bond } \\
\text { Estimated } \\
\text { Estimated }\end{array}$ \\
\hline $\begin{array}{l}\pi \\
\phi\end{array}$ & $\begin{array}{c}\text { Varying } \\
0.7180\end{array}$ & $\begin{array}{l}\text { Trade penalty for defaulting. } \\
\text { Probability of being not forgiven on the next } \\
\text { period. }\end{array}$ & Sandleris et al. (2004) \\
\hline$\beta$ & 0.953 & Subjective time discount factor. & Arellano (2008) \\
\hline$\alpha$ & 0.5859 & $\begin{array}{l}\text { Parameter of the instantaneous utility function; } \\
\text { weight of home good consumption. }\end{array}$ & Estimated \\
\hline$\kappa$ & 0.8447 & $\begin{array}{l}\text { Parameter of the instantaneous utility function; } \\
\text { corresponds to } 6.441 \text { elasticity of substitution } \\
\text { of export to import. }\end{array}$ & Estimated \\
\hline$\sigma$ & 2 & $\begin{array}{l}\text { Parameter of the instantaneous utility function; } \\
\text { corresponds to }-1 \text { elasticity of intertemporal } \\
\text { substitution. }\end{array}$ & Arellano (2008) \\
\hline$\theta$ & 0.2082 & $\begin{array}{l}\text { Curvature of export-import transformation } \\
\text { function. }\end{array}$ & Estimated \\
\hline$\theta_{0}$ & 0.0467 & $\begin{array}{l}\text { Relative position of export-import transforma- } \\
\text { tion function. }\end{array}$ & Estimated \\
\hline$\theta_{1}$ & 0.1959 & Scale of export-import transformation function. & Estimated \\
\hline
\end{tabular}

Table 2: Parameter values, quarterly data. 
To numerically solve this problem, we use value function iteration to solve each subproblem of the Centralized Equilibrium, which is equivalent to solving The Household Problem In Default and The Household Problem In Good Standing. Each of these value functions converges trivially. The Household Problem is characterized by the maximum of these two value functions, and default occurs where $W$ exceeds $V$. Because both functions are monotone in $y$ and $-b$, for a given value of $b$, they may cross. As discussed in Arellano (2008), we should have a single crossing, which means that there is a single $b(y)$ that defines the maximum level of debt before the country defaults, given a realization of $y$.

In the Argentine default example, the estimate of $\ln (1-\pi)$ is -0.6939 , which implies $\pi \approx 0.5$. We take this estimate as illustrative, as there is no international policy for punishing defaulters, so there is no guarantee that one estimate for $\pi$ should hold in other contexts. We evaluate the model's predictions at various punishment levels, to obtain bounds on plausible outcomes, and to account for potential short-sample biases. Varying the value of $\pi \in\{0.2,0.5,0.8\}$ also serves to demonstrate the effect of the trade channel punishment. We see that the country's default policies and behavior in default is sensitive to the magnitude of the trade channel punishment.

\subsection{Welfare Comparisons}

To understand our model with incomplete markets, we compare its agents' welfare to two extremes: complete asset markets and absent asset markets. With incomplete markets, bankruptcy provides some insurance against uninsurable, idiosyncratic risk, as discussed in Livshits et al. (2007). $\pi$ determines the cost of such insurance, and affects both consumption and expected utility. For comparisons, we set $\pi=0.5$ and other parameters follow Table 2. The expected value function in stationary distribution is -18.4318 and the average volume of the consumption aggregate, $\left(\alpha c^{\kappa}+(1-\alpha) m^{\kappa}\right)^{1 / \kappa}$, is 0.5868 . The certainty equivalent of aggregate consumption is 0.5358 . The

risk premium is $9 \%$, defined as $\frac{E \tilde{c}}{c_{C E}}-1$ where $\tilde{C}$ is the actual aggregate consumption and $c_{C E}$ is an aggregate consumption certainty equivalent.

The first best scenario provides agents with complete asset markets, which implies perfect consumption smoothing. At the other extreme, in financial autarky, the country cannot save or borrow and cannot insure against income shocks. We elaborate on the results in Appendix $\mathrm{C}$ and they are 


\begin{tabular}{|l|l|l|l|l|}
\hline & $\begin{array}{l}\text { Expected } \\
\text { utility }\end{array}$ & $\begin{array}{l}\text { Aggregare con- } \\
\text { sumption CE }\end{array}$ & Risk premium & $\begin{array}{l}\text { CE difference } \\
\text { w/ benchmark }\end{array}$ \\
\hline \hline Benchmark & -18.4318 & 0.5358 & $9 \%$ & \\
Financial Autarky & -19.7300 & 0.5189 & $3 \%$ & $-4 \%$ \\
First Best & -15.3818 & 0.5804 & $0 \%$ & $+8 \%$ \\
\hline
\end{tabular}

Table 3: Welfare comparison.

summarized in Table 3.

\subsection{Equilibrium Results}

We obtain three interesting equilibrium predictions. First, country borrows more if it had a history of negative income shocks, i.e. high current borrowing. Second, the current account is countercyclical, in line with data and Aguiar and Gopinath (2006). Third, positive shocks to income depreciate the home currency. The borrowing policy result is immediate, as it is a consequence of risk-aversity of a representative consumer. Most endogenous default papers have this result.

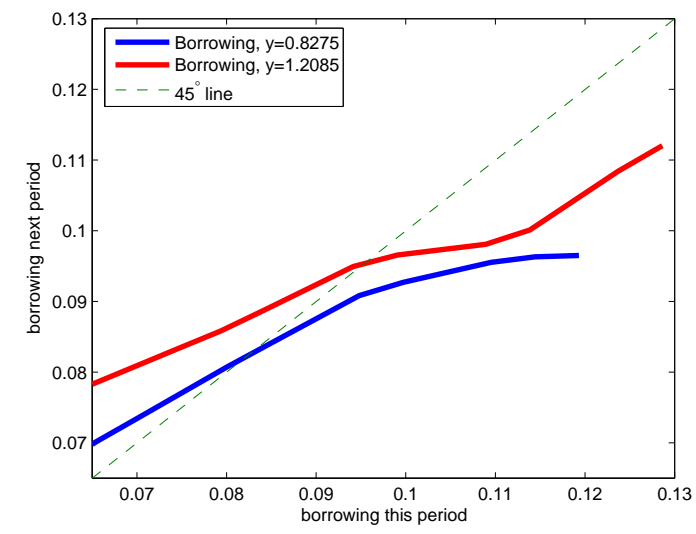

Figure 3: Borrowing policy. Curves stop on right at the point of default.

Our countercyclical current account (Figure 4) is consistent with data and, as Aguiar and Gopinath (2006) point out, nontrivial. In a partial equilibrium, positive shocks would induce savings and a positive current account, but if the interest rate is endogenous, it falls with positive income shocks (because the probability of default is counter cyclical) and spurs borrowing. Arel- 
lano (2008) has a pro-cyclical current account, and Aguiar and Gopinath (2006) shows that in their framework, without demand for trade, the current account's correlation depends on the specification of income process. In our model, the current account is governed by consumer preferences for foreign goods, the importing technology and consumption smoothing. In this richer trade environment, the behavior of the current account does not just mirror the agents' borrowing policy. As our major contribution relies on the trading process that we model, we treat this result as a sign that our trading process properly approximates reality.

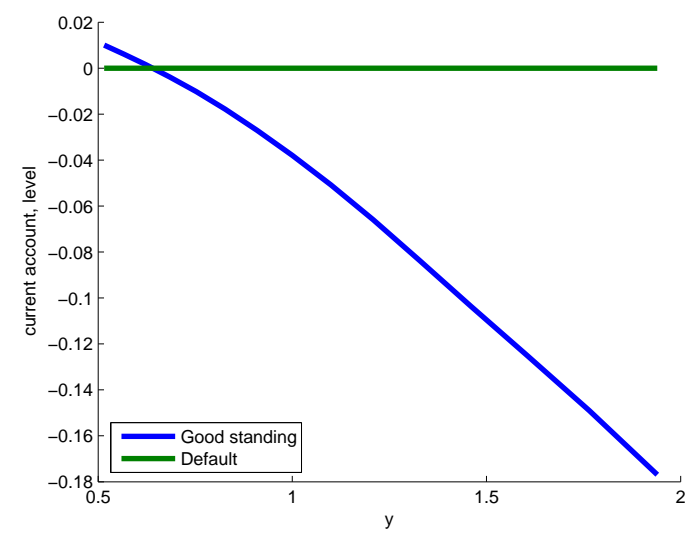

Figure 4: Current account conditional on output in stationary distribution.

The counter cyclical exchange rate is a new result in the endogenous default literature, though Chari et al. (2002) and others establish a similar result in data and in various models. Chari et al. (2002) shows that a fairly standard RBC can generate counter cyclical real exchange rate movements. The intuition within our model is that with an increase in $y$, the country's possibility frontier in terms of $(c, m)$ moves outwards. Consumption of both goods increase because the goods are normal. Since the marginal utility of consumers abroad goes down with additional exports, the exchange rate must rise with the increase in demand for foreign goods. It is important, however, to understand that foreign consumers in the model have no income shocks. To compare our result to the data, one must consider potential shifts in the world's demand function, which would manifest itself in Equation (4) and may shift the tangency point in Figure 2.

Notice also that the exchange rate is higher in default, though not $\frac{1}{1-\pi}=2$ times higher that happens because of the change in trade volumes due to substituting away from imports. The penalty shifts the line down, but the households are also able to adjust their consumption basket, 


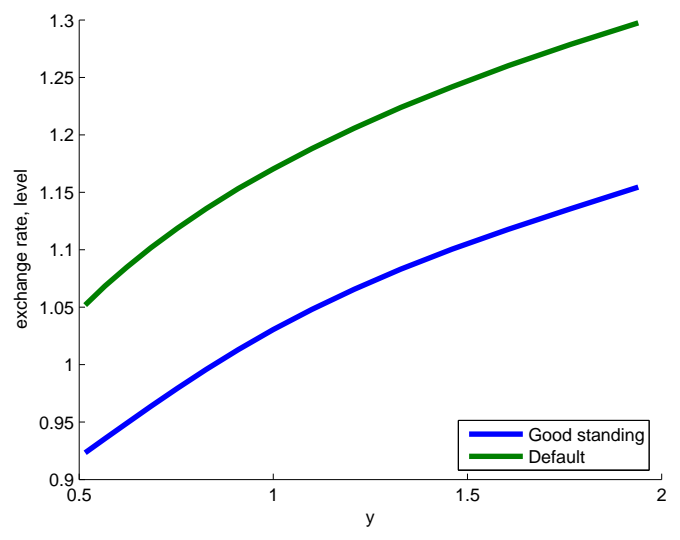

Figure 5: Exchange rate conditional on output in stationary distribution.

and due to the curvature of Equation 4, this affects the exchange rate. As discussed earlier, we could generate a depreciation with linear trade technology, but the nonlinearity due to $\theta<1$ allows for this additional freedom. As the data reveal, there is variation in the size of depreciation and trade volumes tend to shift, both consistent with our preferred parameterization.

\subsection{The Effect Of Penalty Levels}

Figure 6 depicts the default decision threshold, the debt such that the country defaults if borrowing goes any higher. The small penalty case, $\pi=0.2$, in which very little debt can be supported recalls the result of Bulow and Rogoff (1989). As in Aguiar and Gopinath (2006) and Arellano (2008), the sustainable debt increases in $y$; which makes the interest rate spread counter cyclical. The right panel of Figure 6, demonstrates, that the borrowing limit does not increase as fast as $y$, so that an expansion does not imply that a borrower can support a higher percentage of debt. This monotone slope, however, reflects the particular parameterization. With different specification (namely, low $\theta$ ), it can yield an interestingly U-shaped borrowing limit. With this result, recessionary countries with low $y$, have greater incentive to stay in good standing because they expect the negative shock to persist; and countries with high output realizations are also less likely to default; however, in the middle, countries default on much smaller debt level.

The penalty value changes the exchange rate adjustment post default, as seen in Figure 7 . The exchange rate change pictured is calculated as the difference between the exchange rate in a default 

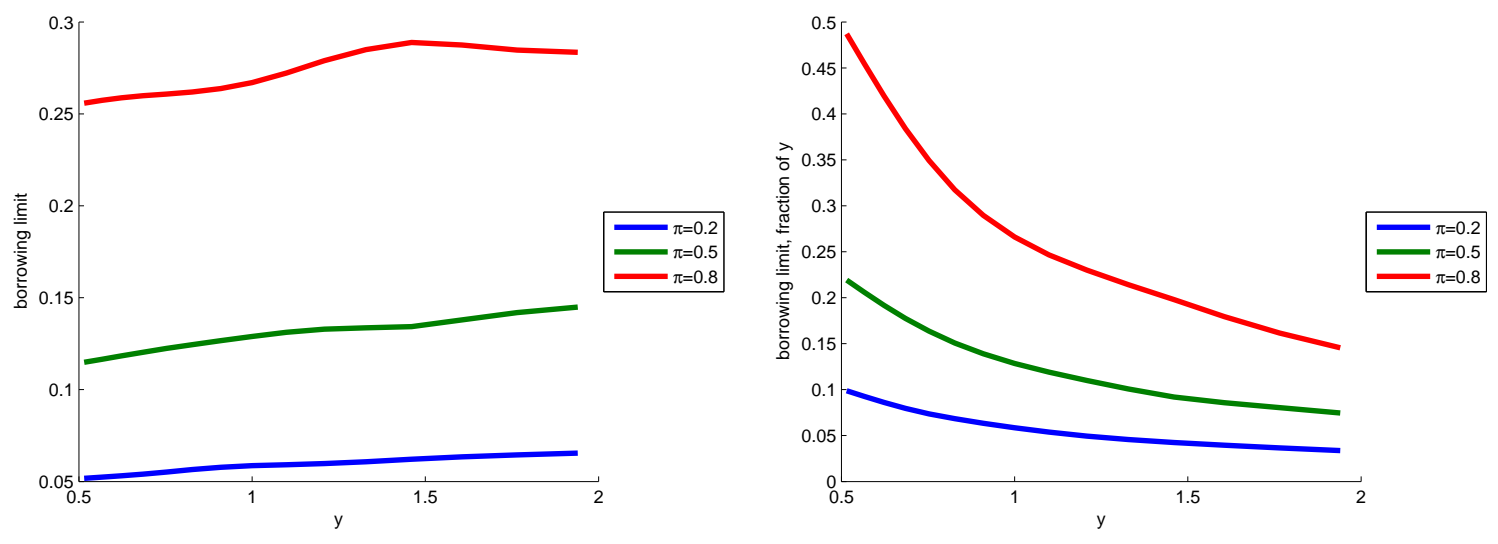

Note: Argentine had debt of around $30 \%$ of GDP at the end of 2001, and normalized detrended GDP of 0.95 .

Figure 6: Default decision borrowing threshold.

state and the exchange rate just before the default. That is, if the country has a debt that leaves it indifferent between defaulting and remaining in good standing, what would be the difference of exchange rates in these two cases? This thought experiment about the moment of default is close to thinking about two otherwise equal countries, one slightly below the default threshold, and one just above. Such a comparison isolates the change purely as a response to default decision. The figure reveals that the level of penalty determines the size of the depreciation. However, the country moderates some welfare damage by substituting domestic product for import consumption. The amount of depreciation does not depend much on the country's position in the business cycle.

Figure 8 (left) illustrates the substitution behavior of domestic households. Country seem to have the same consumption policy at the moment of default independently of the level of $\pi$, that's why consumption policy before default is represented by a single line (this qualitatively holds for other parameterizations). As the trade channel penalty rises, the substitution effect becomes stronger. Figure 2 reveals the link between the change in the makeup of the consumption basket and the exchange rate that we highlighted earlier. Home good consumption is a normal good, and in a default state, an increase in income leads to an increase in consumption; while in the good standing state, higher income allows the country to borrow more, somewhat negating the decreasing returns to scale of import-export relation. A positive shock to income in a defaulted country will lead to increased consumption of home goods; a positive shock in non-defaulted country can lead to a more than one-for-one increase in exports. 


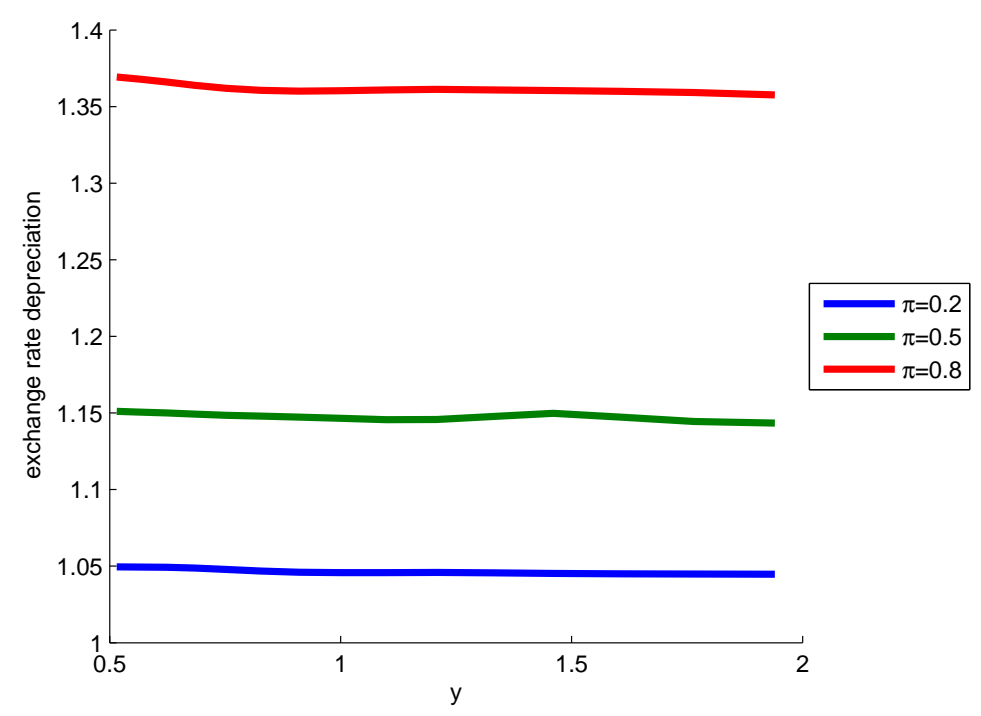

1.15 on this figure means that foreign goods cost $15 \%$ more after default than before default. Penn World Tables report $18 \%$ change of PPP index between 2001 and 2002 .

Figure 7: Exchange rate drop due to default.

Figure 8 (right) demonstrates the pattern of import's share in consumption. Decreasing returns to scale of the export-import relation make the dependence on $y$ negative: countries in expansion export ever greater amounts to receive additional units of imports. Trade channel penalties have both direct effects on the level of import (by construction of the model), and indirect effects through substitution. As in the data, proportional expenditure on imports falls following default; countries in expansion after default benefit from not servicing the debt (which they would have to if they did not default), which instead they can spend on consumption, including imports. Notice that share of imports for high $y$ countries exceeds $(1-\pi)$ times the corresponding value before default.

Figure 9 shows the change in capital account and trade balance at the moment of default decision. The trade balance improves more drastically in countries in downturn and the penalty level contributes significantly to the change size. The difference between the change in trade balance and change in capital account is the change in assets inflow. This might involve foreign currency reserves of respective central bank. Particularly, it implies that a country that defaults in a cyclical expansion and faces $\pi=0.8$ would have to come up with additional assets equal up to $5 \%$ of GDP. Combined with a policy of fixed exchange rate and capital controls, that extra inflow can create a greater than necessary nominal money mass, resulting in inflation. 

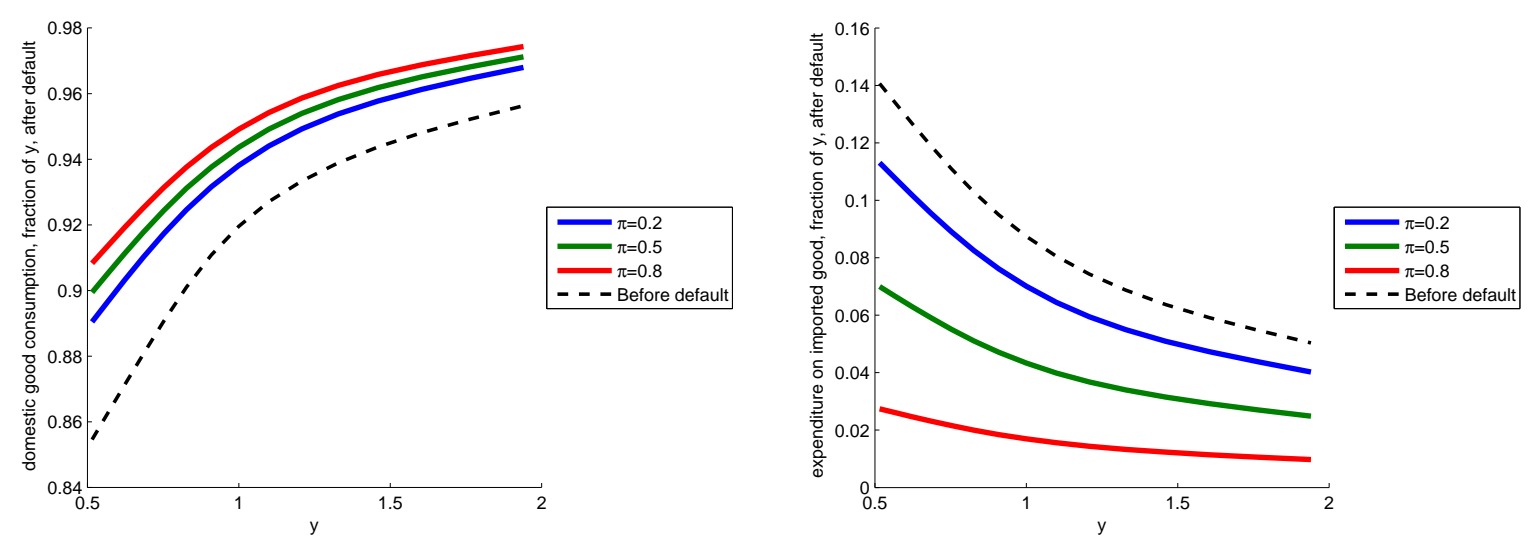

Figure 8: Domestic good consumption (left) and foreign good expenditure (right).
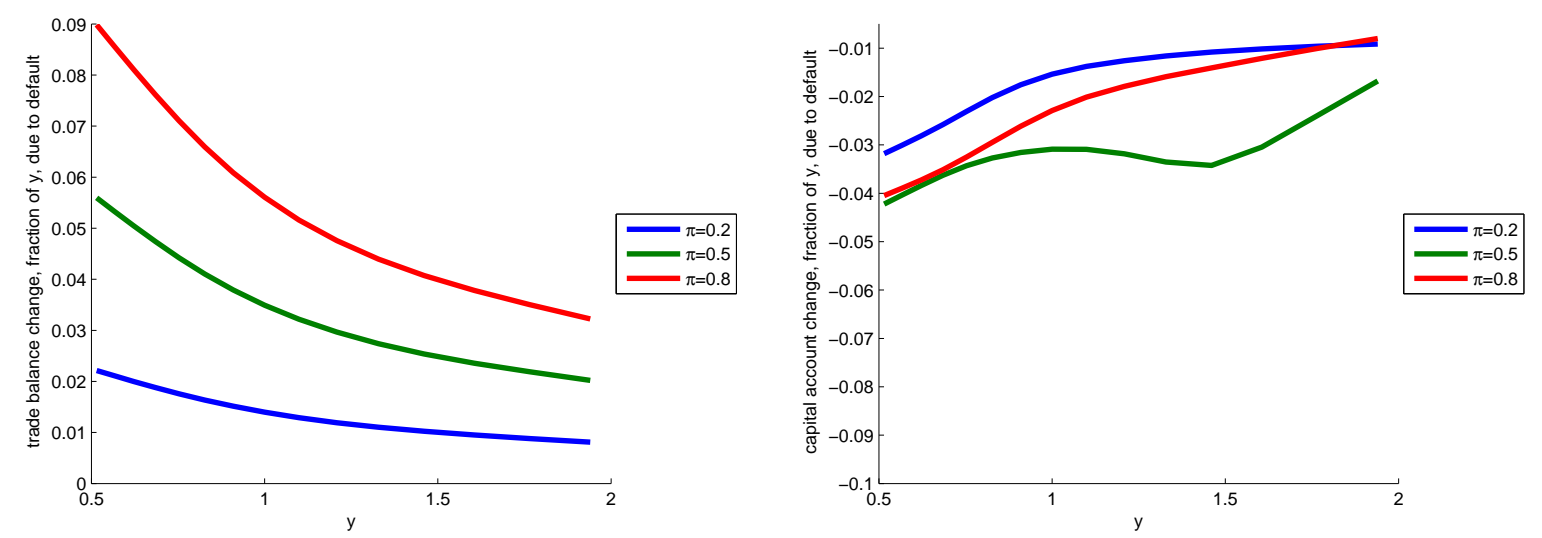

Figure 9: Trade balance (left) and capital account (right) changes at default.

To summarize, a higher trade channel penalty leads to: (a) greater household adjustment through the domestic consumption basket, and trade quantities, (b) higher sustainable debt, and (c) greater exchange rate depreciation.

\subsection{Comparative Statics}

Figure 10 summarizes the expected differences that should arise in cross-country data. The parameters we consider are a change in preferences for imports ( $\alpha$ decreased by 0.1 ), a change in ability to forgive ( $\phi$ increased by 0.1 ) and a change in variance of income ( $s^{2}$ doubled the value). The penalty $\pi$ in benchmark case is set at 0.5 . 

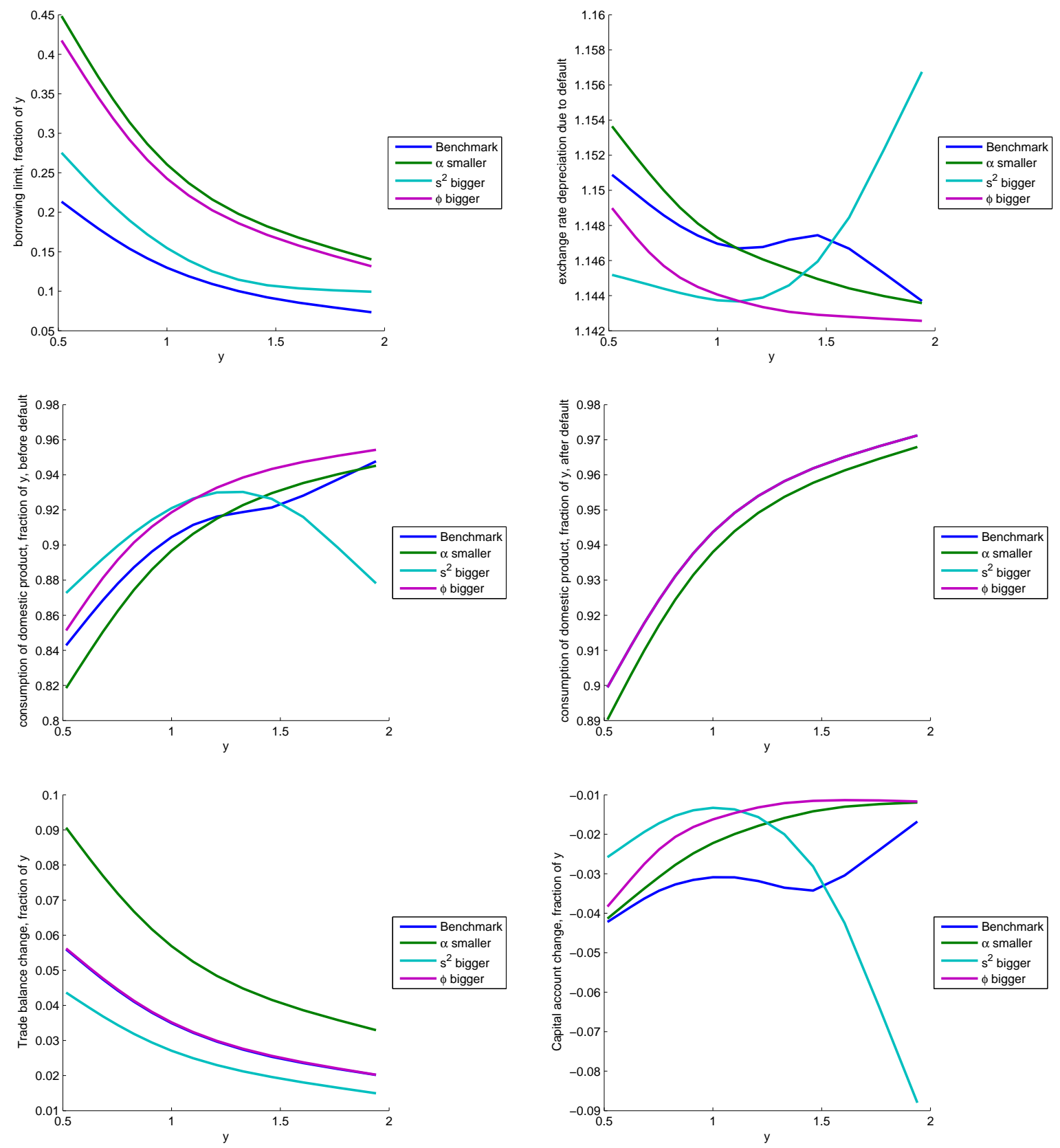

Figure 10: Comparative statics. 
Changing $\alpha$ affects the willingness to default. A country that is less import-oriented defaults sooner and consumes less import in all states. A rapid change in tastes toward home consumption could precipitate default. Consider a government with debt just below the maximum allowable with a certain value for $\alpha$; then, if this sovereign suddenly cared less about the import component of consumption, the level of allowable debt will shift down, possibly below the existing stock. In a populist coup, the new government might internalize the preferences of a different social group, one which consumes relatively fewer imports. This abrupt change of tastes of the sovereign's constituency - if combined with severe pre-existing debt — could result in default and explain some of the "inexcusable" defaults of Tomz (2007).

Loading this experiment on $\alpha$ with so much meaning is knowingly problematic. It is not actually a story consistent with our model, as our CES preferences are homothetic, so a poorer social strata should still have the same demand for imports. Further, our country's household is representative. If a coup implies a change to the preferences that the sovereign internalizes we should have to justify this with some explicit strategy for aggregation a diverse population. In the simplest case, our result is equivalent to a model in which a sovereign that puts full weight on its median constituent. Then, if this groups changes, the preferences upon which it acts would also change.

After default, there is a stronger improvement in trade balance when $\alpha$ is lower, because a lower $\alpha$ country will forego more home consumption in both relative and absolute respects. The new preference regime, by consuming fewer imports, moves down the decreasing returns importexport technology, and so in the aftermath of a default, can sell into a "steeper" market.

The variance of the income process does not notably affect the patterns of trade adjustment relation, either before or after default. However, it affects the default decision through the financial exclusion penalty. This does not necessarily conflict with the Bulow and Rogoff (1989) finding that financial exclusion cannot sustain debt, because we also exclude countries from saving while in bankruptcy. Countries in expansion are more motivated to sustain debt than medium-range countries. The intuition is that high income variance countries obtain higher benefits from maintaining good standing in order to be able to smooth consumption in the future.

Also, observe that the variance of the composition of import and home goods is higher when $y$ is high, and therefore the impact of increased variance is stronger on the right tail of income distri- 
bution. That leads to greater aversion to financial autarky, and consequently, to bigger tolerance of debt. Therefore, countries with higher income volatility might actually be safer for investors than steady economies.

The value of $\phi$ affects the cost of default, but once the choice between defaulting and staying prudent has been made, $\phi$ does not affect other tradeoffs, and therefore does not change the policies significantly. The bigger is $\phi$, the worse is a country's cost of default and this its aversion becomes even stronger if it is currently experiencing an expansion. However, bigger $\phi$ demands more defiance from international lenders: longer punishment means loss of positive NPV projects and restraining selves from exports of the punished country. These concerns over enforcement are explored more in Wright (2001), but we just take as given that penalties are credible.

The comparative statics demonstrate that our model is qualitatively robust to parameter values, and provide additional insights into parallel problems (such as the consequences of populist uprisings and international risk management). The existing literature noted that business cycle fluctuations do not account for a significant fraction of historical default episodes. Our comparative statics demonstrate how changes in underlying parameters immediately result in significantly different equilibrium strategies - and confuse the identification of the business cycle contribution. Moreover, we can see that default boundary condition on debt shape differently with respect to output fluctuations with respect to these parameters; countries will demonstrate different default behavior. Even "inexcusable" in Tomz (2007) sense behavior is not outside of offered model's scope; it only implies certain heterogeneity of parameters.

The top right plot of Figure 10 demonstrates that changing parameters do not change equilibrium depreciation much (and parameters that are changed, are changed by a large value). In fact, only two parameters seem to matter for depreciation: $\kappa$ and $\pi$. Other parameters, chosen to match Arellano (2008) do not affect equilibrium default depreciation, which seems to be arising from the combination of CES utility function and the proportional penalty. With respect to other parameters, our model is (knowingly) ill-suited to match certain moments of the data. For example, without long-term contracts Chatterjee and Eyigungor (2009) suggests models will not be able to match default frequency without undue manipulation of other parameters. In the interest of conservatism, we kept many parameters from the literature. Equilibrium depreciation, our chief concern, depends mostly upon the few parameters that we have discussed. 


\section{Conclusion}

Our paper introduces a model that accounts for the systematic linkage between sovereign default and real exchange rate depreciation. Countries interact with the rest of the world for two reasons: they borrow to smooth consumption over the business cycle and trade for goods that cannot be produced at home. They may default on their borrowing, but misbehaving on the international stage hurts their international trade. A country in default has to export more units of its own production for the same amount of imports. Consumers substitute away from the foreign good, and the new exchange rate, the equilibrium price of foreign goods, depreciates. Because trade disruption is costly in terms of welfare, it reduces a country's willingness to default and allows it to sustain positive debt.

Prior research has noted this empirical connection, but has not explicitly modeled it. Other quantitative models capture the contribution of output fluctuations to the default strategy; however, they consider international markets only as imperfect insurance against stochastic income shocks, abstracting from the desire for differentiated goods from abroad. Here, we have highlighted the importance of international trade. Our trade channel penalty allows a country to support a realistic level of debt before default. Furthermore, the country's maximum borrowing limit is not necessarily increasing with income, a feature observed in the data but difficult to match with other models. We explore the model's response to changes in determinants such as income volatility and penalty duration. The qualitative results of these parameter manipulations are generally consistent with common intuition. We investigate their effects on default and trade policy, and generate policy recommendations for lenders.

In this exercise, we calibrated to data from Argentina to demonstrate the predictions of our import-export mechanism, which is the real innovation of our paper. The parameters obtained from this calibration were consistent with reasonable predictions for the default decision and subsequent international adjustments. Future research might try to match other default episodes more closely. From this basic model, we can also integrate nominal fluctuations and financial flows to capture inflation and credit crunches. This paper, however, elides nominal concerns to emphasize and clarify the real factors behind the default-linked depreciation.

We begin the discussion about how international trade parameter changes could modify the incentives to default. It seems that more import-dependent countries default less frequently. Future 
work should more formally consider a mixed-model of default. A particularly promising avenue is to integrate parameter risk into endogenous variables, e.g. how does the probability of a coup effecting preferences for abroad goods modify the interest rate's default premium? Our discussion also raises a new potential for models with heterogeneous agents and competing interests. Our simple model, considering trade and default, can be fruitfully combined with various other branches of the study of crises. 


\section{References}

Aguiar, M. And G. Gopinath (2006): "Defaultable Debt, Interest Rates and the Current Account," Journal of International Economics, 69, 64-83.

Arellano, C. (2008): "Default Risk and Income Fluctuations in Emerging Economies," American Economic Review, 98, 690-712.

Arteta, C. And G. Hale (2008): "Sovereign debt crises and credit to the private sector," Journal of International Economics, 74, 53 - 69.

Beers, D. T. And J. Chambers (2003): "Sovereign Defaults: Heading Lower into 2004," Research Report 09/2003, Standard and Poor's RatingsDirect.

Bulow, J. And K. Rogoff (1989): "Sovereign Debt: Is to Forgive to Forget?" American Economic Review, 79, 43-50.

Chari, V. V., P. J. Kehoe, and E. R. McGrattan (2002): "Can Sticky Price Models Generate Volatile and Persistent Real Exchange Rates?" Review of Economic Studies, 69, 533-63.

Chatterjee, S. And B. Eyigungor (2009): "Maturity, indebtedness, and default risk," Tech. rep.

Das, S., M. J. Roberts, And J. R. Tybout (2001): "Market Entry Costs, Producer Heterogeneity, and Export Dynamics," Nber working papers, National Bureau of Economic Research, Inc.

De Paoli, B. And G. Hoggarth (2006): "Costs of Sovereign Default," Bank of England Quarterly Bulletin, Fall 2006.

Eaton, J. And M. Gersovitz (1981): "Debt with Potential Repudiation: Theoretical and Empirical Analysis," Review of Economic Studies, 48, 289 - 309.

Hodrick, R. J. and E. C. Prescott (1997): "Postwar U.S. Business Cycles: An Empirical Investigation," Journal of Money, Credit and Banking, 29, 1-16.

Hummels, D. (2001): "Time as a trade barrier," Research report, Purdue University. 
Hummels, D. And P. J. Klenow (2005): "The Variety and Quality of a Nation's Exports," American Economic Review, 95, 704-723.

Livshits, I., J. MacGee, And M. Tertilt (2007): "Consumer Bankruptcy: A Fresh Start," American Economic Review, 97, 402-418.

Rose, A. K. (2005): "One Reason Countries Pay Their Debts: Renegotiation and International Trade," Journal of Development Economics, 77, 189 - 206.

RuhL, K. J. (2003): "Solving the Elasticity Puzzle in International Economics," mimeo, University of Minnesota.

Sandleris, G., G. R. Gelos, And R. Sahay (2004): "Sovereign Borrowing by Developing Countries: What Determines Market Access?" IMF Working Papers 04/221, International Monetary Fund.

Todd, W. F. (1991): "A History of International Lending," in Research in Financial Services, ed. by G. Kaufman, Greenwich, Conn.: JAI Press, vol. 3, 201-289.

Tomz, M. (2007): Reputation and International Cooperation: Sovereign Debt across Three Centuries, Princeton, NJ: Princeton University Press.

Tomz, M. And M. L. J. Wright (2007): "Do Countries Default in Bad Times?" Journal of the European Economic Association, 5, 352-360.

Wright, M. L. J. (2001): "Limited commitment: Theory with applications to repudiation risk," Ph.D. thesis, University of Chicago. 


\section{A Centralized Equilibrium}

At the beginning of the game consumer chooses whether he wants to default or not is Household's New Problem:

$$
U(b, y)=\max _{h \in\{0,1\}} h W(y)+(1-h) V(b, y)
$$

The borrowers's problem conditional on not defaulting this period is New Problem With No

\section{Default:}

$$
\begin{aligned}
V(b, y) & =\max _{c, x, m, b^{\prime}} u(c, m)+\beta E U\left(b^{\prime}, y^{\prime}\right), \\
\text { s.t. } & \\
c+x+b & =y+q\left(y, b^{\prime}\right) b^{\prime}, \\
m & =f(x), \\
\ln y^{\prime} & =\rho \ln y+\epsilon, \epsilon \sim \mathcal{N}\left(0, s^{2}\right) .
\end{aligned}
$$

If country chooses to default, then its value function is a solution to New Problem In Default:

$$
\begin{aligned}
W(y) & =\max _{c, x, m} u(c, m)+\beta E\left(\phi W\left(y^{\prime}\right)+(1-\phi) U\left(0, y^{\prime}\right)\right), \\
\text { s.t. } & \\
c+x & =y+\Pi, \\
m & =(1-\pi) f(x), \\
\ln y^{\prime} & =\rho \ln y+\epsilon, \epsilon \sim \mathcal{N}\left(0, s^{2}\right) .
\end{aligned}
$$

Combined with the Zero Profit Condition, solution to this problem will give the same values as the Equilibrium we want to study. However, it does not give the value of the exchange rate. We recover this from the first-order conditions to the New household choice problems:

$$
e_{V}(y, b)=\frac{\partial u\left(c_{V}(y, b), m_{V}(y, b)\right)}{\partial m} / \frac{\partial u\left(c_{V}(y, b), m_{V}(y, b)\right)}{\partial c}
$$




$$
e_{W}(y)=\frac{\partial u\left(c_{W}(y), m_{W}(y)\right)}{\partial m} / \frac{\partial u\left(c_{W}(y), m_{W}(y)\right)}{\partial c}
$$

\section{B Estimation}

To test our model's implications, we estimated various parameters using Argentine data. In many cases, we could have better characterized the Argentine data generating process with different parametric functional forms, but this would distract from the model we introduce. Our goal is not to match Argentine perfectly, though there is a certain virtue in doing so, but we fear that additional complexity will impede one's intuition for the model. Rather we decided to stay in the simple world of $\mathrm{AR}(1)$ processes and (relatively) linear functions to provide a reasonable test of the quantitative implications of our model .

\section{B.1 Output Time Series}

Output $y$ was calibrated to quarterly deseasoned per-capita GDP in constant prices, which was assumed to follow $\mathrm{AR}(1)$ process. It was not detrended because trend seems to be too small. Regression equation is

$$
\ln y_{t}-m=\rho\left(\ln y_{t-1}-m\right)+\epsilon_{t}, \epsilon_{t} \sim N\left(0, s^{2}\right)
$$

$m$ is the normalizing coefficient. Estimates are following:

\begin{tabular}{llc}
\hline \hline Variable & Coefficient & (Std. Err.) \\
\hline$m$ & $9.0669^{*}$ & $(0.1464)$ \\
$\rho$ & $0.9878^{*}$ & $(0.0081)$ \\
$s$ & 0.0258 & \\
\hline
\end{tabular}

Table 4: Estimation results, output dynamics, One star denotes 1\% significance.

A Dickey-Fuller test does not reject a unit root hypothesis for this process, therefore, given standard deviations may be biased downward. Controlling a linear trend does not help to reject the unit root hypothesis, nor does it give much different estimates of other parameters. 


\section{B.2 Consumer's Utility Parameters}

Utility function parameters were estimated from the first-order condition of consumer. $c$ was taken to be equal to consumption (both private and public) plus investment from INDEC data. Nominal imports quantity was deduced from import value from INDEC data divided by the exchange rate, obtained from European Bank.

$$
\ln e=\ln \frac{1-\alpha}{\alpha}+(\kappa-1)\left(\ln \frac{c / y}{m / y}\right)
$$

Estimates are following:

Table 5: Estimation results, output dynamics.

\begin{tabular}{llc}
\hline \hline Variable & Coefficient & (Std. Err.) \\
\hline $1-\kappa$ & $0.1553^{*}$ & $(0.0440)$ \\
$\ln \frac{1-\alpha}{\alpha}$ & $-0.3472^{*}$ & $(0.0972)$ \\
\hline
\end{tabular}

Within a 95\% condfidence interval, we can conclude that $\kappa<1$, so goods are not perfect substitutes, and $\alpha>0.5$. With the obvious transformations of the estimation in Table $5, \kappa=0.8447$ and $\alpha=0.5859$. Again, the regression is not perfect. An $\operatorname{ARIMA}(2,1,1)$ model specification seems to perform better to correct for the nonstationarity for which exchange rates are notorious.

\section{B.3 Import-Export Equation}

The most interesting regression seems to be the trade equation. It was estimated by nonlinear least squares:

$$
\ln m_{t}=\ln (1-\pi) I(\text { punished at } t)+\ln \theta_{1}+\theta \ln \left(x_{t}-\theta_{0}\right)+\epsilon_{t} .
$$

Here we decided to allow the import-export equation to be nonlinear ( $\theta$ not necessarily equal to 1 ), have a fixed cost $\left(\theta_{0}\right.$ is not necessarily equal to 0$)$. We do not explore why it happens that firms can earn positive profits in equilibrium; we just allow estimates to signal us about that. These degrees of freedom are not necessary, and they don't drive our main result. However, they certainly help to achieve better fit of default responses. 
For numbers on imports and exports, we smoothed quarterly fluctuations on the INDEC data using an HP filter Hodrick and Prescott (1997) with smoothing parameter 400.

Table 6: Estimation results, import-export conditions.

\begin{tabular}{llc}
\hline \hline Variable & Coefficient & (Std. Err.) \\
\hline$\theta$ & $0.2082^{*}$ & $(0.0763)$ \\
$\theta_{0}$ & $0.0467^{*}$ & $(0.0070)$ \\
$\theta_{1}$ & $0.1959^{*}$ & $(0.0409)$ \\
$\ln (1-\pi)$ & $-0.6939^{*}$ & $(0.0256)$ \\
\hline
\end{tabular}

The estimate of $\ln (1-\pi)$ suggests that $\pi$ is equal to 0.5 with surprising precision. We will use this number in model outcome calculation; to make sure we don't fall victim of regression's non-robustness, we also solve for the model with $\pi=0.8$ and $\pi=0.2$, so whatever is the real value of $\pi$, the real outcome will be lying in between these two models' outcomes. As for values of $\theta \mathrm{s}$, they are not too far away from the ones a person can get by estimating the 1993-2000 subsample of "no default."

We estimate this equation on a subsample of 1993-2003. The reason why we do not continue on the sample of 2004 and further is that it seems that Argentine does not have the same instant recovery of terms of trade after default as we have assumed in the model. Consider the time series of $u_{t}=$ $\frac{\Delta m_{t}}{\Delta x_{t}} \frac{x_{t}}{m_{t}}$, a measure of elasticity of change in import with the change of export, presented on Figure 11. One can see an approximately constant elasticity during most of 1990s, then a decline, a series of definite changes in structure of equation, and an increase in 2004, with a stable more than 2 elasticity after default. The big jump down in 2001 is what we try to capture with $(1-\pi)$ multiplier. In this estimation, we allow for a period of adjustment, a process of re-establishing of connections lost in 2001. Imports do not only increase due to an increase in $x$, but also from a renewed efficiency of trading. Summarizing, we don't use the data after default because we believe that after forgiving the default import depends not only on export on the same period, but also on export on previous periods. 


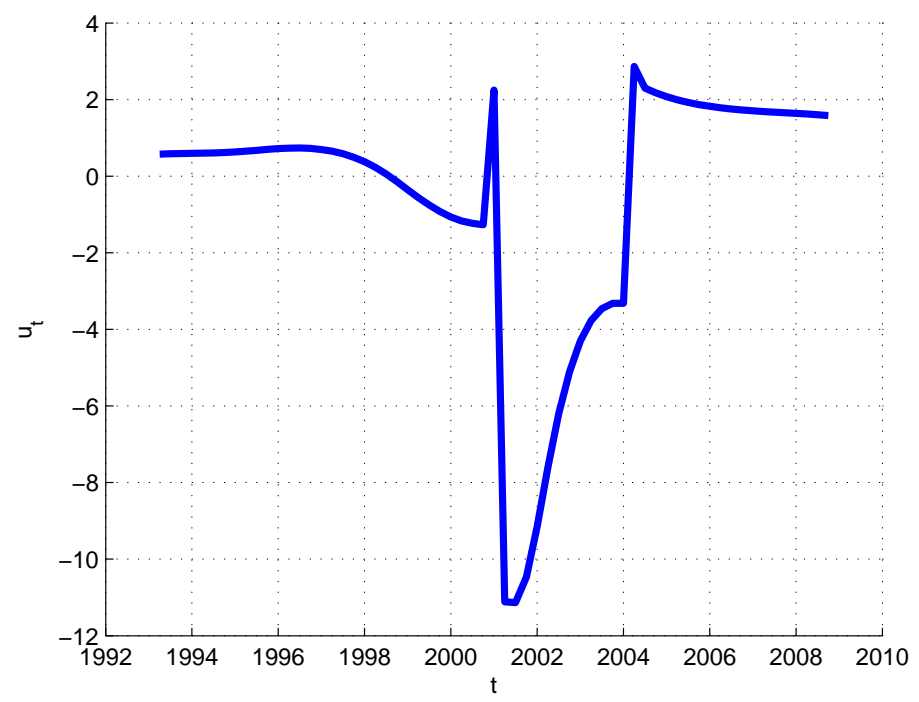

Figure 11: Time series of $u_{t}=\frac{\Delta m_{t}}{\Delta x_{t}} \frac{x_{t}}{m_{t}}$, "sample elasticity."

\section{Solving for First Best}

Solving the "first best" general equilibrium is equivalent to solving the following convex programming problem, instead of the stochastic problem established above. Values for endogenous variables carry the subscript $z_{f b}$

$$
V(\bar{y})=\max _{c_{f b}, m_{f b}}\left\{\alpha c_{f b}^{\kappa}+(1-\alpha) m_{f b}^{\kappa}\right\}^{(1-\sigma) / \kappa}+\beta V(\bar{y})
$$

subject to:

$$
\begin{aligned}
c_{f b}+e_{f b} m_{f b}+b & =\bar{y}+\Pi, \\
m_{f b} & =\theta_{1}\left(x_{f b}+\theta_{0}\right)^{\theta} .
\end{aligned}
$$

The solution to which gives us

$$
\begin{aligned}
\bar{y}+\Pi & =c_{f b}+e_{f b} \theta_{1}\left(x_{f b}+\theta_{0}\right)^{\theta}, \\
\alpha c_{f b}^{\kappa-1} & =e_{f b}^{-1}(1-\alpha)\left(x_{f b}+\theta_{0}\right)^{\theta(\kappa-1)}, \\
m_{f b} & =\theta_{1}\left(x_{f b}+\theta_{0}\right)^{\theta} .
\end{aligned}
$$


The importer's problem, gives two more conditions for the optimal quantity of exports and the level of profits.

$$
\begin{aligned}
& \Pi_{f b}=e_{f b} m_{f b}-x_{f b}, \\
& m_{f b}=\theta_{1}\left(x_{f b}+\theta_{0}\right)^{\theta},
\end{aligned}
$$

which gives optimal levels of of $x_{f b}, \Pi_{f b}$ :

$$
\begin{aligned}
x & =\left(e_{f b} \theta_{1} \theta\right)^{1 /(\theta-1)}-\theta_{0}, \\
\Pi & =\left(e \theta_{1}\right)^{-1 /(\theta-1)}\left(\theta^{-\theta /(\theta-1)}-\theta^{-1 /(\theta-1)}\right)+\theta_{0} .
\end{aligned}
$$

